\title{
GOG AND MAGOG (YAKJUJ WA MAKJUJ) STORIES IN SUNDANESE MANUSCRIPTS
}

\author{
Faiz Karim Fatkhullah ${ }^{1}$ \\ ${ }^{1}$ (Universitas Islam Nusantara/fkfatkhullah@gmail.com) \\ Tajudin Nur ${ }^{2}$ \\ 22(Universitas Padjadjaran/tajudin.nur@unpad.ac.id) \\ I. Syarief Hidayat ${ }^{3}$ \\ ${ }^{3}$ (Universitas Padjadjaran/syahid.hd47@gmail.com) \\ Undang A. Darsa ${ }^{4}$ \\ 4(Universitas Padjadjaran/undang.a.darsa@unpad.ac.id)
}

\begin{abstract}
Gog and Magog will appear in the end of the world as a sign of doom. Their mysterious figure, making the story Gog and Magog interesting as well as a debate among experts. This study aims to reveal the reception of the Sundanese to the story of Gog and Magog which is represented by three Sundanese texts: Saifu Ad-Dharīb (SaD), Lajaj Dajal (LD), and Nawādirul 'Ulūm (NU). This study used a descriptive qualitative method with the reception theory approach. Of the three manuscripts, there are a diversity reception informing the advantages and disadvantages of each manuscript. The reception of who is Magog, LD's text calls them communist descendants. Regarding its existence, the $\mathrm{SaD}$ manuscripts say they are on Mount Qaf. Related to their numbers, the three manuscripts mention the numbers very much; SaD mentioned they have 400,000 troops, and each of them gave birth to 1000 offspring. NU's manuscripts reveal all objects will be destroyed and humans will become their prey. SaD's manuscripts mention their deaths due to massive winds; $L D$ manuscripts say they died from being attacked by thousands of mosquitoes, while $\mathrm{NU}$ manuscripts say they died of disease.
\end{abstract}

Keywords:

Gog and magog; signs of doomsday; philology; sundanese manuscripts

DOI: $10.19105 /$ ojbs.v13i1.2233

\section{A. Introduction}

Believers in the end times will face various slander or test, whether physical slander or inner slander. Not a little at that time people who in the morning of believers, in the afternoon have moved kafir, in the morning of the infidel, in the afternoon of believers. ${ }^{1}$ In addition, another slander of life filled with injustice, tyranny, oppression and killing

1 "Hadis Muslim No. 169," accessed April 25, 2018, http://www.carihadis.com. 
of believers takes place in various places. In such circumstances, not a few believers who hope and pray that God will send someone who will return the condition to be safe, peaceful, just, peaceful and prosperous. Such conditions in the teachings of religions are called messianism, which is the ultimate salvation of human race's ultimate salvation concept with the emergence of someone who returns it to a time of peace. Islam recognizes it by the name of al-Mahdi. ${ }^{2}$

The appearance of al-Mahdi is a sign of doomsday is near. In the time of al-Mahdi ${ }^{3}$ the lives of Muslims become peaceful, justice, safe, prosperous. The welfare of the day is described as an age of wealth, until there are people with tithe of gold but no one wants to receive it, because everyone is rich and prosperous.

Seeing much of the territory conquered by al-Mahdi, the Dajal appears angrily. ${ }^{4}$ Muslim who are in a state of peace and prosperous, are disturbed by the presence of Dajal. AlMahdi who at that time leads the people try to calm them with the news of the

2 Abu Fatiah Al-Adnani, Petaka Akhir Zaman: Detik-Detik Menuju Hari Kehancuran Alam Semesta (Surakarta: Granada Media Tama, 2016). 222.

${ }^{3}$ Muhammad bin Abdirrahman Al-'Uraifi, Al-'ālam Al-Akhīr: Ahdāś Al-Qiyāmah as-Șugrā Wa AlKubrā Wa Mā Ba'dahā Bi as-Ṣuwar Wa AlTauḍīhāt Min Al-Qur'ān Wa as-Sunnah asSahīhah (Riyadh: Dar at-Tadmuriyyah, 2012).

${ }^{4}$ Abi al-Husain bin al-Hajjaj bin Muslim, Sahih Muslim (Riyadh: Dar al-Salam Li al-Nashr wa alTauzi', 2000). No. 5217. descent of Prophet Isa. Al-Adnani ${ }^{5}$ explains that after the Prophet Isa came down in the East Tower, in Damascus City, the Muslims joined in search of the Dajal who was on his way to Baitul Maqdis. Prophet Isa then met the Dajal in the area of 'Aqabah Afiq. When he saw the Prophet Isa, the Dajal ran away which was then pursued by Prophet Isa close to the Bab Ludd (Ludd Gate) Dajal then killed by Prophet Isa with his spear.

Under the leadership of Prophet Isa and al-Mahdi, Muslims live in the shade of Islam. They again felt the peace, justice and prosperity after the killing of Dajal. This is as in Abu Hurairah's Hadith "Thūbā li'aisyin ba'da al-Masih" is indeed a happy life after the killing of al-Masih al-Dajal. ${ }^{6}$ However, not for some time, slander came back to them. This time slander arises from a host of physical features and its existence became controversial among the scholars, namely Gog and Magog. Beings who cannot be defeated by anyone, including Prophet Isa.

The study of Gog and Magog is as interesting as the Dajal story. It can be argued that this study ranks second after discussion of Dajal. In fact, the studies were conducted by Westerners and published in international journals. For example, studies related to Gog and Magog have been done by Nicholas $M$.

\footnotetext{
5 Al-Adnani, Petaka Akhir Zaman: Detik-Detik Menuju Hari Kehancuran Alam Semesta, 2016. 369.

${ }^{6}$ Mustafa Abu an-Nasr As-Sa'labi, Sahih Asyratu As-Sā'at Wa Wasfu Liyaumi Al-Ba'si Wa Ahwāli Yaumi Al-Qiyāmah, 2nd ed. (Jeddah: Maktabah al-Sawāadi li al-Tauzi', 1994). 265-266.
} 
Railton entitled Gog and Magog: the History of Syimbol. ${ }^{7}$ Sandra Sáenz-López Pérez conducted a study entitled $\mathrm{La}$ Representación De Gog Y Magog Y La Imagen Del Anticristo En Las Cartas Náuticas Bajomedievales. ${ }^{8}$ Jasson Dittmer conducts a scientific publication entitled Of Gog and Magog: The Geopolitical Visions of Jack Chick and Premillennial Dispensationalism. ${ }^{9}$ Lyda Lee published his scholarly work on Gog and Magog under the title The enemies within: Gog of Magog in Ezekiel 38-39. ${ }^{10}$

The story of Gog and Magog is not only contained in the Qur'an, but also in the Torah, the Bible. The Qur'an mentions the story while telling the story of King Zulkarnaen, a pious king who enjoys adventure around the world. Zulkarnaen's odyssey has gone all the way to the eastern hemisphere and western hemisphere, so on this basis according to Al-Wabil ${ }^{11}$ he is named after Zulkarnaen, the king who explores the two western and eastern hemispheres. In another opinion it is called Zulkarnaen

\footnotetext{
7 Nicholas M. Railton, "Gog and Magog: The History of a Symbol," The Evangelical Quarterty 1 (2003): 23-43.

8 Sandra Sáenz-lópez Pérez, "La Representacion De Gog y Magog," AEA LXXVIII, no. 311 (2005): 263-76.

9 Jason Dittmer, "Of Gog and Magog: The Geopolitical Visions of Jack Chick and Premillennial Dispensationalism," ACME: An International E-Journal for Critical Geographies 6 (2007): 278-303.

10 Lydia Lee, "The Enemies Within: Gog of Magog Modern Political Identifications of Gog," HTS Teologiese Studies/Theological Studies 73, no. 3 (2017): 1-7.

${ }^{11}$ Yusuf bin Abdillah bin Yusuf Al-Wabil, "Asyrātu As-Sā'ati” (Dar Ibnu al-Jauzi, 1983). 373.
}

because he controls Persia and Rome. Another opinion states that it is called Zulkarnaen because his head resembles two horns. ${ }^{12}$

Gog and Magog according to the majority of scholars seen from the origin of the word, both are the words' 'ajam (non arab) which is part of the isim gairu munsarif. Another opinion says that both are Arabic, but there is a summary of the origin of the word. Another opinion says that it comes from the word ajī al-nār, the flaming fire. Another argument comes from the word al-āj, quickly hostile, another argument from the word al-ujāj, the very boiling water. ${ }^{13}$

Ibn Hajar in the book of Fathu al$B \bar{a} r i^{14}$ narrated from al-Fakihi that Zulkarnaen lived during the time of Prophet Ibrahim. Both had met at the time of both hajj. Meanwhile, according to 'Atha from ibn' Abbas, that Zulkarnaen entered the Grand Mosque then shook hands with Prophet Ibrahim. From this information, it is found that Zulkarnaen was a pious Muslim who was given power by God to conquer the eastern and western regions. $\mathrm{He}$ is not the pagan Alexander Macedonia. In

12 Mahir Ahmad As-Sufi, Asyrāt Al-Sā'ati Al'Alāmāt Al-Kubrā (Beirut: Syirkah Abnā Syarīf alAnshārī li al-Thibā'ah wa al-Nashr wa at-Tauzī', 2010). 134.

13 Ibnu Hajar in As-Sa'labi, Sahih Asyratu AsSā'at Wa Wasfu Liyaumi Al-Ba'si Wa Ahwāli Yaumi Al-Qiyāmah. 227.

${ }^{14}$ In Mahmud Rajab Hamadi Al-Walid, Kasyfu AlMinan Fī 'Alāmāti Al-Sā'ati Wa Al-Malāhim Wa AlFitan: Ru'yat Limustaqbal Al-'Alam Al-Islāmi Fī Dhau'i Al-Kitāb Wa Al-Sunnah (Beirut: Dār ibnu Hazim Li at-thibā'ah wa an-Nasyr wa at-Tauzi', 2002). 278. 
addition, the distance of both also lies approximately two thousand years. ${ }^{15}$

Gog and Magog are classified by the scholars as a close marker of the great apocalypse (as-Sa'ah al-Kubra), according to the majority of scholars (jumhūr 'ulamā) are children of Adam's descendants, precisely from the descendants of Noah, and more precisely from the path of Yafits. It is based on a Hadith (although according to some scholars it is dha'if) from Abi Hurairah r.a. said that. Messenger of Allah said, "Noah had a son; Sam, Ham, and Yafits, from Sam were born Arabs, Persians, and Romans. From Ham was born Qibthi, Barbarian, and Sudan. Meanwhile, from Yafits was born the Gog and Magog, Turkey, and Shaqalibah". From this Hadith, it can be mentioned that the Yakjuj is a people or tribe, and Makjuj is a people or a tribe as well. Both of them are very large nations, ${ }^{16}$ because of every Gog and Magog gave birth to a thousand descendants, as hadith conveyed by Ibn Mas'ud r.a. which is contained in the history of Sahih Ibn Hibban. "Indeed Gog and Magog when one of them gave birth, then came out of his bones a thousand breeds."17

The scholars differ on who Gog and Magog are and where they are now.

\footnotetext{
${ }^{15}$ Al-'Uraifi, Al-'ālam Al-Akhīr: Ahdās̀ Al-Qiyāmah as-Ṣurā Wa Al-Kubrā Wa Mā Ba'dahā Bi asȘuwar Wa Al-Tauḍīhāt Min Al-Qur'ān Wa asSunnah as-Șahīhah. 31.

${ }^{16}$ As-Sufi, Asyrāt Al-Sā'ati Al-'Alāmāt Al-Kubrā. 126-127.

17 As-Sufi. 130.
}

To disclose it, the discussion is returned to the story of King Zulkarnaen's, when he reached between two mountains, acquired a group of people who barely understood the language. They ask for his help because often terrorized by the people next to him, namely Gog and Magog. The people asked King Zulkarnaen to make a strong dividing wall that cannot be broken down by Gog and Magog. This incident was recorded in the Qur'an of Surah al-Kahfi: 92-95:

(92) Until when he had come between two mountains, he found in the presence of the two hills a people hardly understood by his speech (93) They said: "O Zulkarnaen, verily Gog and Magog are the ones who make mischief in the land, can we give you a payment to make a wall between us and them?" (94) Zulkarnaen said: "What has been authorized by my Lord to me against it is better, then help me with power (man and tools), so that I make a wall between you and them (95).

The above verse is part of the emergence of different receptions and interpretations regarding the existence of Gog and Magog. Mahmud Rajab Hamadi al-Walid ${ }^{18}$ mentions that Gog and Magog are a great nation of humanity that is now confined in a place flanked by mountains in the eastern

\footnotetext{
18 Mahmud Rajab Hamadi Al-Walid, Kasyfu AlMinan Fī 'Alāmāti as-Sā'ati Wa Al-Malāhim Wa AlFitan: Ru'yat Limustaqbal Al-'ālam Al-Islāmi Fì Dhau'i Al-Kitāb Wa as-Sunnah (Beirut: Dar ibnu Hazim La aThiba'ah wa an-Nasyr wa at-Tauzii', 2002). 273.
} 
region. They will come out if it is desired by Allah. That's when they will make damage in every place he passes. AlWalid $^{19}$ tends to agree that the Gog and Magog referred to are the Chinese and their neighbors, because they are a religionless nation (atheist) and unallected. Muslims try to avoid it and keep their cattle from the cruelty of Gog and Magog. In fact, if Gog and Magog get rivers or lakes, then in an instant the lake is exhausted and dried by their drinking. ${ }^{20}$

The historians differed on the existence of a wall Zulkarnaen made to confine Gog and Magog. A German researcher at the beginning of the 15th century Sidabarger states that the wall was near the town of Tarfud known as the iron gate. This opinion was reinforced by the Spanish historian Kalapego in 1403 AD who declared the wall of the iron city on the road between Samarkand and India, and that was the wall built by Zulkarnaen. There is no doubt that it is the Chinese, because their inhabitants now account for onethird of the earth's population or one billion more. ${ }^{21}$

Gog and Magog are creatures whose traits have been described by the Messenger (Muhammad) of the Hadith narrated by Ibn Harmalah from his aunt who stated that "... They are a nation with wide-faced features, slanted-eyed, blond-haired, faced-like a layered

\footnotetext{
${ }^{19}$ Al-Walid. 279.

${ }^{20}$ Al-Walid. 276.

${ }^{21}$ Al-Walid. 280-281.
}

shield. ${ }^{22}$ Meanwhile, Musa Turoichan alQudsi ${ }^{23}$ mentions three kinds of Gog and Magog properties: (1) their form is like a bee (wasp) that is 120 cubits high, (2) they have rectangular and very wide ears, if one ear sleep is used as a blanket and another used as a base, (3) among them there is a height of approximately one inch. Nevertheless, these narrations are widely regarded by scholars as an unfounded narrative. ${ }^{24}$ However, Muhammad bin Ghaits bin Ghaits ${ }^{25}$ concludes from several Hadiths concerning Gog and Magog as follows,

Gog and Magog are the two great breeds of the descendants of Prophet Adam. They came out after the killing of Dajal by Prophet Isa. They came out as a great plague like humans and as a sign of the great apocalypse which was followed by the blowing of the trumpet and doomsday. They are still confined to the wall of Zulkarnaen until now and will come out at the appointed time. God guarded the wall even though they tried every morning until evening hollowed it. They are a nation that obeys its leaders. No one was able to kill them even

\footnotetext{
22 Abu Fatiah Al-Adnani, Petaka Akhir Zaman: Detik-Detik Menuju Hari Kehancuran Alam Semesta (Surakarta: Granada Media Tama, 2016). 405.

${ }^{23}$ Musa Turoichan Al-Qudsy, Munculnya Dajjal Dan Imam Mahdi Di Akhir Zaman (Terjemah Fafirru Ila Allah), Pertama (Surabaya: Ampel Mulia Surabaya, 2004). 55.

${ }^{24}$ Muhammad Ghaits bin Ghaits, "Ahādis Asyrāth As-Sā'ati Wa Fiqhuhā" (Jami'ah Muhammad alKhamis Mamlakah al-Garbiyyah Rabat, 2013).

${ }^{25}$ Ghaits. 562-564.
} 
though at that time the Prophet Isa was alive. Allah kills Gog and Magog because of their arrogance and evil against the inhabitants of the heavens and the earth by sending worms to their necks so that they are like the death of grasshoppers. After that birds were sent to carry their carcasses. Then a great downpour swept over the remains of the carcass until the earth was like a clean mirror. The destruction of Gog and Magog took place in Jabal Khumur, the mountain in the Baitul Maqdis area. After the destruction of Gog and Magog, the earth became a blessing, life became peaceful, and Islam became dispersed.

Muhammad bin Abdurrahman al'Uraifi $^{26}$ declares the walls of Gog and Magog in the area of Munqathi', Turkey, ie between Armenia and Azerbeijan. This opinion is reinforced by $\mathrm{Al}-\mathrm{Qudsy}{ }^{27}$ that Gog and Magog were besieged between two mountains; Amlas and Munqathi'. Mount Amlas is a very slippery mountain that can not be passed by humans. While Mount Munqathi' ie the mountain behind it there is only the ocean. Between the two mountains that Zulkarnaen make the walls of iron with copper coated liquid. Gog and Magog every morning until sunset continues to gnaw and pierce

${ }^{26}$ Al-'Uraifi, Al-'ālam Al-Akhīr: Ahdās̀ Al-Qiyāmah as-Ṣugrā Wa Al-Kubrā Wa Mā Ba'dahā Bi asȘuwar Wa Al-Taudīhāt Min Al-Qur'ān Wa asSunnah as-Șahīhah. 312.

27 Al-Qudsy, Munculnya Dajjal Dan Imam Mahdi Di Akhir Zaman (Terjemah Fafirru Ila Allah). 55. until now. However, the wall will not be broken until the specified time arrives.

With all his pride and arrogance that no one can match, the Prophet Isa and the Muslims who fled at Mount Khamar prayed for Allah to bring them down. Not long afterwards, Gog and Magog finally destroyed by Allah. Regarding the destruction of this creature there is a variety of opinions. One suggestion mentions God lowering the gnawing worms, so they die all without exception. Another opinion says that they were inflicted with the devastation of a devastating cyclone as it was inflicted on the 'Ad people, so that in about one hour they died and perished. ${ }^{28}$ Meanwhile, Sheikh Mahmud Athiya Muhammad $\mathrm{Ali}^{29}$ mentioned that they were drowned or buried in the bowels of the earth and some were killed by small and abject animals. However, the majority of the opinions state that they were destroyed by the attacks of 'naghaf' animals, a type of worm that bit their necks to death, as reported by Imam Ahmad's Hadith from Abu Hurairah. ${ }^{30}$

From the opinion of the scholars above, it appears that there are various greetings and interpretations of them against Gog and Magog. It is evident

\footnotetext{
${ }^{28}$ Al-Qudsy. 55.

29 Mahmud Athiyah Muhammad Ali, Tanda Berakhirnya Dunia: Menyingkap Tabir Datangnya Kiamat Berdasarkan Al-Qur'an (Solo: Tinta Medina, 2014). 199.

${ }^{30}$ Muhammad Ahmad 'Abdu Al-'Aziz, An-Nihāyah Fitan Wa Ahwāl Ākhir Al-Zamān: Mukhtashar Nihāyat Al-Bidāyah Li Ibnu Katsir (Al-Qahirah: Maktabah al-Turāts al-Islamy, 1988). 84.
} 
that the story in the Qur'an becomes the inspiration for the birth of a new literary reception, ${ }^{31}$ such as the story of Gog and Magog. It happened also to the people of Sunda, West Java, Indonesia. They received the story of Gog and Magog from mouth to mouth which they wrote in a script. Among the texts discussing the signs of doom, including the stories of Gog and Magog, are the texts of the Saifu Ad-Dharīb (SaD), the Dajal Layang (LD), and the Nawādirul 'Ulūm (NU).

Manuscripts as a legacy of ideas of the people of his day, need to be reviewed to reveal the extent to which the development of their understanding, especially on the story of Gog and Magog. This study aims to reveal how the welcome and interpretation of the Sundanese, West Java, which is represented in the three Sundanese texts above, on the story of Gog and Magog. This is very interesting to examine, because the story of Gog and Magog has spread to the layers of the world community, including the Sundanese people, whose implications will be found a variety of greetings or receptions.

\section{B. Method}

This study uses a qualitative descriptive method with a reception theory approach. The steps of this study begin with the collection of the manuscript, description or analysis of the text, and interpretation of the contents of the text. A text that can be read by the

31 Ach. Ghazali Salim, "Peran Kitab Suci AlQur'an," OKARA 1, no. X (2015): 1-16. 2. general public, transliteration and translation needs to be done. From the translation result, the text can be interpreted and contextualized, which by Robson this philological process is called "presenting and interpreting" the text. $^{32}$ Transliteration and translation are vital because it is a bridge for literacy and language transfer from the original to global characters and languages. ${ }^{33}$

The object of this research study consists of three Sundanese texts written in Pegon characters; Saifu adDharib (SaD), Layang Dajjal (LD), and Nawadirul Ulum (NU). The SaD text was copied in the 1920s, the LD text was not known for the year of copying, while the $\mathrm{NU}$ manuscript was copied around the end of the 60s. The SaD text was transliterated and translated by Faiz Karim Fatkhullah, ${ }^{34}$ LD text by Winda Fitriyani, ${ }^{35}$ and $\mathrm{NU}$ text by Imam Cici Mutaqin. ${ }^{36}$ The SaD and NU texts are written in prose, while the LD text is written in the form of song or wawacan. The SaD manuscript was examined by Faiz Karim Fatkhullah in the journal

\footnotetext{
32 S.O. Robson, Prinsip-Prinsip Filologi Indonesia (Jakarta: Pusat Pembinaan dan Pengembangan Bahasa dan Universitas Leiden, 1994). 12.

33 Baroroh Baried, Pengantar Teori Filologi (Jakarta: BPFF UGM, 1994). 65.

${ }^{34}$ Faiz Karim Fatkhullah, "Saifu Aḍ - D pharīb : Text Edition and Study of Signs of Doomsday" (Universitas Padjadjaran, 2019).

35 Winda Fitriyani, "Naskah Layang Dajjal 'Kebangkitan Makhluk Laknatullah' Suntingan Teks Dan Terjemahan" (Universitas Padjadjaran, 2017).

36 Imam Cici Mutaqin, "Naskah Nawadirul Ulum 'Tanda-Tanda Hari Kiamat': Edisi Teks Dan Terjemahan" (Universitas Padjadjaran, 2016).
} 
Humanus, but he discussed the signs of another apocalypse, namely Dajal, The Reception of the Dajjal Story in The Saifu ad-Dharib. ${ }^{37}$

$\mathrm{SaD}$ manuscript is written by $\mathrm{KH}$. Tubagus Ahmad Bakri in which 12 signs of the Kubra doomsday and 36 signs of the sugra doomsday were discussed there, including 8 predictions made by Sunan Gunung Jati. The apocalypse of the Kubra in the SaD text, namely; the arrival of Imam Mahdi, the departure of the Dajjal, the descent of the Prophet 'Isa, the coming of Ya'juj wa Ma'juj, the appearance of smoke, the emergence of wind from the south of Yemen, the rising of the sun from the west, the removal of the Ka'ba, the issuance of three eclipses, he appointed the Qur'an, and the appearance of fire from Aden. ${ }^{38}$

The NU script contains the signs of the revelation of the grave, such as: the exit of Imam Mahdi, the fall of Prophet Isa, the exit of the Dajjal, the ruined Ka'bah. In addition, other discussions include, the age of the world, the creation of the Prophet Adam and his surrounding story, and the state of the earth before Adam descended from heaven. ${ }^{39}$ Meanwhile, the LD script generally contains the story of the Antichrist, the exit of Imam Mahdi, the

37 Faiz Karim Fatkhullah, Tajudin Nur, and Undang Ahmad Darsa, "The Reception Of Dajal Story In The Saifu Ad-Dharib," Humanus 17, no. 1 (March 20, 2018): 37, https://doi.org/10.24036/humanus.v17i1.8779.

${ }^{38}$ Fatkhullah, "Saifu Aḍ - D harīb : Text Edition and Study of Signs of Doomsday." vi.

39 Mutaqin, "Naskah Nawadirul Ulum 'TandaTanda Hari Kiamat': Edisi Teks Dan Terjemahan." fall of Prophet Isa, the Prophet Khidir, and the exit of Gog and Magog. ${ }^{40}$

Of the three texts above, the researcher took one object of study contained in three texts above, namely the story of Gog and Magog. To examine this story, the author uses the theory of reception. Reception is a theory in literature that considers the reader as the greeter of a literary work. Literature since its birth, according to Jauss, continues to be appreciated by readers, so that literary works are built dynamically with a variety of responses from one generation to the next. ${ }^{41}$ Furthermore, Jauss said that the interaction and communication of the reader with literary works will occur dynamically because the reader has their own expectation horizon which is very different from the author of the literary work. $^{42}$ A copyist of the manuscript as well as a reader, often gives responses and remarks on the copy he copied and then adjusts to the culture at that time. ${ }^{43}$

\section{Results}

From this research, the results obtained that the story of Gog and Magog received a reception from the Sundanese community is relatively

\footnotetext{
40 Fitriyani, "Naskah Layang Dajjal 'Kebangkitan Makhluk Laknatullah' Suntingan Teks Dan Terjemahan."

41 Jabrohim, Metodologi Penelitian Sastra, ed. Jabrohim, 3rd ed. (Yogyakarta: PT Hanindita Graha Widya, 2003). 110.

42 Jabrohim. 109.

43 A Teeuw, Sastra Dan Ilmu Sastra, 5th ed. (Bandung: Pustaka Jaya, 2015). 165.
} 
diverse. Of the three manuscripts above, the uniqueness is very visible when the story was drawn to the local culture of Sunda. The text of SaD tends to interpret the story of Gog and Magog as in the texts of Hadith. Meanwhile, LD texts tend to interpret more contemporary, and NU texts tend to interpret more according to the local culture of Sunda.

Judging from the title, there are various receptions. The text of $\mathrm{SaD}$ which means "sabetan pedang", does not reflect that this text of its contents tells of the signs of doom, especially Gog and Magog. Meanwhile, the LD text which specifically means "Dajal story", contains not only the Dajal's story, but also other doomsday signs, including Gog and Magog. The NU manuscript, seen from its meaning means "ilmu-ilmu langka", precisely in it tells the signs of doom, not containing scarce or unfamiliar sciences. This is the form of response and interpretation of the reader of the story of the signs of doom, including the story of Gog and Magog.

When talking about Gog and Magog, the text of SaD explains that they are descendants of Yafits bin Nuh bin Abi Turk. According to this text, Gog and Magog have three physical characters; there is a height of 120 cubits, there is a tall and big body the same, there is a long ear and can be used as bedding, and there is a magnitude between one and two span.
Ari Ya'juj wa Ma'juj dawuhan Hasan Bașri/ asalna turunan Yāfis̀ bin Nuh 'alaihi as-salām wa Yāfiś Abu/ at-Turk. Wa Yajuj wa Ma'juj min at-Turk ${ }^{44}$... kitu keneh sifatna aya tilu rupa. Aya jangkung sampai seratus/ duwa puluh hasta. Aya nu saruwa jangkung jeung rubakna awak/ ceulina nilep sabeulah dijieun amparan ku manehna. Aya anu/ sajengkal aya anu duwa jengkal ${ }^{45}$

According to Hasan Basri that Gog and Magog are descendants of Yafits bin Nuh 'alaihi al-salam. Yafits himself is the father of the Turkish nation ${ }^{46} \ldots$ there are three forms of their character: there is a height of 120 cubits, there is a height equal to the width of his ears so that if his ears folded can be used for his own base, and there is a height one or two span ${ }^{47}$

Meanwhile, in the text of LD it is mentioned that Gog and Magog are communist descendants. In addition, according to this text the form of Gog and Magog consists of three kinds. However, it is not explained in detail in the form. In this manuscript mentioned that the form of Gog and Magog high and large, there is a high 10 inch, and some are square-shaped body. ${ }^{48}$

44 Tubagus Ahmad Bakri, Saifu Ad-Dharīb (Purwakarta, 1922).

45 Bakri.

${ }^{46}$ Bakri.

${ }^{47}$ Bakri.

${ }^{48}$ Fitriyani, "Naskah Layang Dajjal 'Kebangkitan Makhluk Laknatullah' Suntingan Teks Dan Terjemahan." 
tilu rupa jangkung sareng gedè

luhur

jangkungna sapuluh depa,

sarta awakna pasagi.

Yajuja jeung Wamajjuja,

bangsa seuweu anak putu[na]

kamènis,

nu gede Yajuja estu

three forms of Gog and

Magog are large and tall

ten cubits high

and the square shaped-

body

Gog and Magog

the nation of a thousand

descendants of the

communists

really Magog is very big ${ }^{49}$

As in the text of NU, Gog and Magog are not mentioned at all about their physical form or whose offspring they are.

From the data above, it appears that the text of $\mathrm{SaD}$ is a text that interprets the figure of Gog and Magog closer to the original text, ie Hadith. Meanwhile, the LD text interprets Gog and Magog with a communist nation. If the text of the LD interprets Gog and Magog as communist, it can conceal that choice in certain communist-minded countries and has a very large population. ${ }^{50}$ The choice is on Russia and China. In the Torah, that Gog and Magog or more commonly known as Gog and Magog, is a nation that occupies the region of North Asia, which

\footnotetext{
${ }^{49}$ Fitriyani.

${ }^{50}$ Al-Walid, Kasyfu Al-Minan Fì 'Alāmāti Al-Sā'ati Wa Al-Malāhim Wa Al-Fitan: Ru'yat Limustaqbal Al-'Alam Al-Islāmi Fì Dhau'i Al-Kitāb Wa AlSunnah. 273.
}

is now called Russia (formerly Soviet). ${ }^{51}$ This opinion is shared by Muhammad Ahmad Al-Mubayyadh ${ }^{52}$ which mentions Gog and Magog inhabiting the region of Central Asia (to the north). The same is stated by John Nelson Darby, he interprets that it is not wrong if that is meant in the book of Ezekial: 38 'Rosh' ie Russian state. ${ }^{53}$ However, in Ezekial, Gog and Magog are believed to be the state of Russia will soon destroy the state of Israel. This is as expressed by Ronald Reagan to James Mills. ${ }^{54}$

Furthermore, if Gog and Magog were referring to the Chinese, it was in accordance with the opinions of the commentators and historians, among them Ahmad Mustofa Al-Maraghi, Sayid Qutub, Abu al-A'la al-Mawdudi, Shaykh Thanthawi, etc. which mentions that Gog and Magog are Tartars and Mongols. They occupy an area that stretches between Tibet, China to the North Sea Ice, and the West stretching from Turkistan to Central Asia, and so on. ${ }^{55}$

In connection with the existence of Gog and Magog, the text of SaD states that Gog and Magog are on Mount Qaf, the place where King Zulkarnaen built the barrier “... ayeuna eta Ya'juj wa/ Ma'juj

${ }^{51}$ Hisyam Kamal Abdu Al-Hamid, Ya'jūj Wa Ma'jūj Qādimun, 1st ed. (Al-Qāhirah: Dār al-Kitāb al'Arabi, 2006). 138.

52 Muhammad Ahmad Al-Mubayyadh, AlMausū'ah Fì Al-Fitan Wa Al-Malāhim Wa Asyarāti as-Sā'ati (Al-Qahirah: Muassasah Al-Mukhtār Li An-Nasyr wa At-Tauzī', 2006).

53 Dittmer, "Of Gog and Magog: The Geopolitical Visions of Jack Chick and Premillennial Dispensationalism." 290.

${ }^{54}$ Dittmer. 294-295.

${ }^{55}$ Al-Hamid, Ya'jūj Wa Ma'jūj Qādimun. 77-78. 
ayana di luhureun Jabal Qaf dibentengku Raja Żu/ Ikarnaen" now Gog and Magog are on top of Mount Qaf. They are locked up by King Zulkarnaen. ${ }^{56}$

As for the LD text does not mention the location of Gog and Magog. The LD text only mentions that the fortress capable of blocking Gog and Magog was built by Zulkarnaen. At the appointed time, the castle will be destroyed by itself. "Damelna Dulkarnèn raja, kuta bentang burak-barik" the fortress was made by King Zulkarnaen, the fortress will be destroyed someday. ${ }^{57}$

Meanwhile, in NU's manuscript there is no mention of the existence of the Gog and Magog places. In addition, the subject of the barrier of Gog and Magog barriers was not mentioned in it.

The text of $\mathrm{SaD}$ mentions the number of troops of Gog and Magog is 400,000, "Ya'juj wa Ma'juj boga balad 400.000 Ma'juj" Gog and Magog had 400,000 troops. ${ }^{58}$ In this manuscript it is mentioned that Yakjuj will not die before leaving the next generation of 1000, “... Jeung henteu waka paeh hingga boga/ anak sarebu dini hiji Makjuj loba pohara." They will not die before the birth of a thousand descendants of each Majuj, very much. ${ }^{59}$

Meanwhile, the text of the LD mentions the same thing as the $\mathrm{SaD}$ text, when every Gog has 1000 children

\footnotetext{
${ }^{56}$ Bakri, Saifu Ad-Dharīb.

57 Fitriyani, "Naskah Layang Dajjal 'Kebangkitan Makhluk Laknatullah' Suntingan Teks Dan Terjemahan."

${ }^{58}$ Bakri, Saifu Ad-Dharīb.

${ }^{59}$ Bakri.
}

or descendants. The LD text does not specify the number of Gog and Magog numbers. LD mentions the number of Gog and Magog very much and only Allah knows, "Sakureun sèwu anakna, ku lobana teu kawilis. Ngan Allah anu uninga" about a thousand descendants, countless numbers, only Allah knows. ${ }^{60}$

Furthermore, NU's manuscript does not mention the number of Gog and Magog, it only mentions when they die, the carcass is very much. Due to the number of carcasses, so the Prophet Isa cannot meet the road when going down from Mount Tursina. "Aranjeun ngararaos gangguan anu langkunglangkung ku seueurna bangké Ya'juj jeung Ma'juj, henteu aya tempat anu kosong istu heurin nincak kupoharana bangké nyayeud' you feel disturbed because so many carcasses of Gog and Magog, there is no empty place except filled with carcasses. ${ }^{61}$

From the data above, the three manuscripts mention the number of Gog and Magog a lot. The manuscripts of $\mathrm{SaD}$ and LD, both mentioned that every Gog and Magog gave birth to 1000 descendants. Both opinions are in line with the narration in the Hadith of the Prophet narrated by Al-Nawas ibn Sam'an.

The manuscript of the SaD tells the world of the great destruction it

\footnotetext{
60 Fitriyani, "Naskah Layang Dajjal 'Kebangkitan Makhluk Laknatullah' Suntingan Teks Dan Terjemahan."

61 Mutaqin, "Naskah Nawadirul Ulum 'TandaTanda Hari Kiamat': Edisi Teks Dan Terjemahan."
} 
caused when Gog and Magog came out. The manuscripts of SaD depict all kinds of trees, rocks, animals, sea water, river water will all be eaten and drunk by Gog and Magog. "Nu matak/ kaluar pohara ngaruksakna sagala kayu batu sato hewan/cai laut cai wahangan diarinum diharakan ku eta/sakabeh Ma'juj", very devastating damage caused when Gog and Magog. Wood, stone, animals, sea water, lake water, all eaten and drunk by them. ${ }^{62}$

Furthermore, in the LD script depicted the power and greatness of Gog and Magog, no figure can stand against it. Prophet Isa, Imam Mahdi and the believers also hide in Mount Tursina. In fact, all the objects they encounter will be destroyed; stones and wood are eaten, graves will be ravaged, including humans into their food. The ferocity is not up to that, they aim their arrows towards the sky in hopes of killing the angels there.

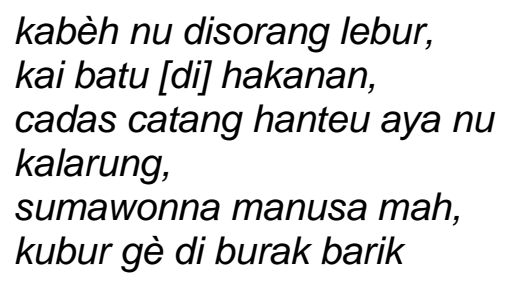

all that are attacked will be destroyed wood and stone will be eaten none of the objects will be missed so do humans the grave was also destroyed. ${ }^{63}$

62 Bakri, Saifu Ad-Dharīb.

63 Fitriyani, "Naskah Layang Dajjal 'Kebangkitan Makhluk Laknatullah' Suntingan Teks Dan Terjemahan."
From the data above, the three manuscripts mention the number of Gog and Magog a lot. The manuscripts of SaD and LD, both mentioned that every Gog and Magog gave birth to 1000 offspring. Both opinions are in line with the narration in the Hadith of the Prophet narrated by Al-Nawas ibn Sam'an.

Meanwhile, NU's manuscript in discussing the damage caused by the discharge of Gog and Magog by mentioning that human life and his property become their threat. That is, humans can also be killed, even eaten by them and their property deprived, "Ya'juj jeung Majuj pohara ngaruksakna kana jiwa manusa jeung harta-harta manusa" Gog and Magog greatly endanger the human lives and human treasure. ${ }^{64}$

From the data above, the three texts have interpreted with the same view, that when Gog and Magog came out all the objects they encountered would be destroyed. The rivers and lakes will dry up because all water is drunk by Gog and Magog, including the water of the Euphrates River and Tigris water (beside Lake Thabaria). ${ }^{65}$

The text of the SaD mentions that there are three places that can not be colonized by Gog and Magog; Mecca, Medina, and Baitul Maqdis. "leu dunya dijajah ku Ya'juj wa Ma'juj/ iwal Makkah Madinah jeung Bait al-Muqaddas" the world is colonized by Gog and Magog

\footnotetext{
64 Mutaqin, "Naskah Nawadirul Ulum 'TandaTanda Hari Kiamat': Edisi Teks Dan Terjemahan."

${ }^{65}$ Muhammad Asad in Railton, "Gog and Magog: The History of a Symbol." 26.
} 
except Mecca, Medina, and Baitul Maqdis. ${ }^{66}$

Meanwhile, the LD text mentions that there are four places that can not be reached by Gog and Magog. However, the LD text does not mention the four places. He mentioned only one place where Prophet Isa and the Believers took refuge from the ferocity of Gog and Magog. That place is Mount Tursina. "Ngan anu opat nagara, ku Yajuja Wamajuja [teu] kapanggih" only four countries can not be entered by Gog and Magog. ${ }^{67}$

The NU script only mentions one place that can not be reached by Gog and Magog. That place is then used as a refuge base by Prophet Isa and the believers, namely Mount Tursina. "Sa(li)la lungsurna Kangjeng Nabi Isa Alaihisalam sareng saréncang-réncangana ti Gunung Tursina, aranjeun ngararaos gangguan anu langkung-langkung ku seueurna bangké Ya'juj jeung Ma'juj" as long as Prophet Isa and his companions descended from Mount Tursina, they were troubled by the many carcasses of Gog and Magog. ${ }^{68}$

From the data above, it can be seen that the three texts respond that there is a place that can be used as a means of shelter from Gog and Magog. However, the receptions given by the $\mathrm{SaD}$ script are more complete. The LD

${ }^{66}$ Bakri, Saifu Ad-Dharīb.

67 Fitriyani, "Naskah Layang Dajjal 'Kebangkitan Makhluk Laknatullah' Suntingan Teks Dan Terjemahan."

68 Mutaqin, "Naskah Nawadirul Ulum 'TandaTanda Hari Kiamat': Edisi Teks Dan Terjemahan." text says there are four places, but it only mentions one place's name in the text. Meanwhile, the NU script only mentions one place, namely Mount Tursina.

In the text of SaD, Gog and Magog were destroyed and died by the wind that God used to destroy the 'Ad. Within an hour, Gog and Magog die all and their carcasses fill the earth, "Ya'juj wa Ma'juj di dunya tujuh tahun dipaehana ku Allah/ diturunan angin anu tilas ngancurkeun kaum 'Ad baheula paral ehna dina waktu sajam sampai geuleuh ieu dunya pinuh ku// bangkai" Gog and Magog live for seven years. They are destroyed by God with the wind used to destroy the 'Ad. They died within an hour, so the world was full of scent. ${ }^{69}$

Meanwhile, the LD script mentions that Gog and Magog were destroyed and killed by the attack of thousands of mosquitoes that entered their ears. They screamed and then died, so their carcasses piled up and filled the earth.

ka malaikat geura turunkeun èta reungit, reungit piran-pirang2 rèbu, sarua jeung anak hayam, panyèrèdan kawas jarum yaza kitu, arasup kana ceulina, Yajuja pating calerit ${ }^{{ }^{0}}$

angels immediately lower mosquitoes thousands of mosquitoes just like chicks they are like needles that pierce into the ear Gog on screaming

\footnotetext{
${ }^{69}$ Bakri, Saifu Ad-Dharīb.

70 Fitriyani, "Naskah Layang Dajjal 'Kebangkitan Makhluk Laknatullah' Suntingan Teks Dan Terjemahan."
} 
From the data above, the three manuscripts mention the number of Gog and Magog a lot. The manuscripts of $\mathrm{SaD}$ and LD, both mentioned that every Gog and Magog gave birth to 1000 descendants. Both opinions are in line with the narration in the Hadith of the Prophet narrated by Al-Nawas ibn Sam'an.

As in the text of NU mentioned that Allah sent torture to Gog and Magog in the form of disease commonly infecting animals that then destroy them. "Ya'juj jeung Ma'juj diturunan siksa ku nu Maha Kawasa ti langit, diturunan panyakit sato hama nu ngaruksak ka maranéhna" Gog and Magog were sent down by Allah from the sky in the form of an animal disease that destroyed them. ${ }^{71}$

From the description above, it appears that all three have their respective interpretations. This indicates that the story of Gog and Magog is welcomed and received very varied. The text of $\mathrm{SaD}$ interprets that the punishment inflicted on Gog and Magog in the form of wind, the LD text interprets it with the mosquito, and the NU text interprets it with illness. All three, if returned to the Hadith (narrated by AlNawwas bin Sam'an) as the source of the emergence of the commentary, only mention al-naghaf, a type of worm. The text of SaD mentions the carcass of Gog and Magog very much and filled the earth. To clean up the pile of carrion God sent birds to bring the carcass to

\footnotetext{
71 Mutaqin, "Naskah Nawadirul Ulum 'Tanda-
} Tanda Hari Kiamat': Edisi Teks Dan Terjemahan." the ocean. The manuscript of $\mathrm{SaD}$ does not tell the subsequent cleansing process after the carcass was gone. Nor does he describe the shape of the vulture bird. "leu dunya pinuh ku//bangkai dileungitkeunana eta bangkai Allah ngutus manuk dipa/ cokan dibuang ka laut" the world is full of carrion. The carcasses were cleansed by God by sending a number of birds carrying the carcass to the sea. ${ }^{72}$

The manuscript LD tells that after the carcass lies, Allah sends down the great rain that sweeps the carcass into the ocean. The LD text instead mentions only the final event of the purge, not telling the previous incident, "Gusti Allah $\mathrm{Nu}$ Agung, ngersakeun datang (na) hujan, cai caah bangkè digusur ka laut" Almighty God wants to bring rain. Water drops and carries the carcasses into the sea. $^{73}$

Meanwhile, NU's manuscripts are more complete. At that time, God sent huge birds to dispose of the carcasses to God's place. Furthermore, after the carcass was absent, Allah sent down a great rain that made the earth clean like a clean dirty plate.

\section{Nu Maha Kawasa ngawurkeun manuk-manuk anu kacida rongkahna Galudra atawa nu sanésna pohara galedéna sagedé-gedé éta bukti. Manuk- manuk mariceunan bangké- bangké sakersana Alloh}

\footnotetext{
72 Bakri, Saifu Ad-Dharīb.

${ }^{73}$ Fitriyani, "Naskah Layang Dajjal 'Kebangkitan Makhluk Laknatullah' Suntingan Teks Dan Terjemahan."
} 
Subhanahuwataa'la. Saterasna Alloh ngucurkeun hujan anu kacida saéna jeung ageungna ngaberesihan kana jagat nepika beresih. Sanggem dina Hadis \{kajulpat\} saperti piring lodor anu diséka tina padaberesihna. ${ }^{74}$

Almighty God sends very valiant and great birds. The birds throw away the carcasses that Allah requires Subhanahu wa ta'ala. Then Allah sends down a great rain so that it can cleanse all the carcasses, as contained in the Hadith, that its cleanness is like a clean plate of its filth.

From the description above, the $\mathrm{NU}$ script is the most complete manuscript in telling the process of cleansing the carcass of Gog and Magog. In addition, NU texts tend to bring the story into local contexts. He analogized and interpreted the carcass of Gog and Magog carcasses with Eagle. Whereas in the text of Hadith only mentioned with a necked bird like a camel's neck. However, since the local community is not all able to imagine birds whose neck is as big as an ostrich, the NU script comes with a local interpretation of the Eagle. In Hindu mythology, the Eagle is the king of birds that is the mortal enemy of the snake. ${ }^{75}$

74 Mutaqin, "Naskah Nawadirul Ulum 'TandaTanda Hari Kiamat': Edisi Teks Dan Terjemahan." ${ }^{75}$ Hery H. Winarno, "Burung Garuda, Dewa Atau Elang Jawa | Merdeka.Com," 2017, https://www.merdeka.com/khas/burung-garudadewa-atau-elang-jawa.html.

\section{Conclusion}

The three Sundanese manuscripts above, various responses and their interpretations of Gog and Magog stories appear. Seen from this reception theory, that the text of $\mathrm{SaD}$ is the most complete manuscript of its speech in telling Gog and Magog, followed by LD text, and then NU script. Judging from the receptions of who is Gog and Magog, the text of $\mathrm{SaD}$ interprets Gog and Magog in accordance with the Prophet's Hadith. Meanwhile, the LD text interprets Gog and Magog inclined to interpretation as contemporary scholars. Seen from the whereabouts of Gog and Magog, the manuscripts of $\mathrm{SaD}$ are the only manuscripts that give reception by mentioning that they are on Mount Qaf. However, the manuscripts of $\mathrm{SaD}$ and the LD script both responded that Gog and Magog were locked up by Zulkarnaen. Judging from the number of Gog and Magog, the three texts responded that their numbers were numerous. However, the manuscripts of $\mathrm{SaD}$ and LD have a common perception that each Gog and Magog gave birth to a thousand descendants. Seen from the awesomeness of Gog and Magog, the three texts give the same reception of their awesomeness when they emerge from the wall made by Zulkarnaen. Seen from a safe place from Gog and Magog, SaD's manuscripts mention there are three places, LD manuscripts mention there are four places, but only one mentioned, and NU manuscripts mention only one place. Seen from the reception 
of Gog and Magog's death, the manuscripts of SaD say that they died as a result of the blowing wind, the LD text states that they died from the attacks of thousands of mosquitoes, and NU's manuscript states that they died from an outbreak of disease. Judging from how the cleaning process of Gog and Magog carcasses, SaD's manuscript mentions that the carcass was washed away by the birds that brought it into the ocean. The LD text states that the carcass was cleansed by the rain. Meanwhile, NU's manuscript states that the carcass was washed away by large birds, while the smells and remains were cleansed through the rain.

\section{References}

Al-Adnani, Abu Fatiah. Petaka Akhir Zaman: Detik-Detik Menuju Hari Kehancuran Alam Semesta. Surakarta: Granada Media Tama, 2016.

_- Petaka Akhir Zaman: Detik-Detik Menuju Hari Kehancuran Alam Semesta. Surakarta: Granada Media Tama, 2016.

Al-'Aziz, Muhammad Ahmad 'Abdu. AnNihāyah Fitan Wa Ahwāl Ākhir Al-Zamān: Mukhtashar Nihāyat Al-Bidāyah Li Ibnu Katsir. AlQahirah: Maktabah al-Turāts alIslamy, 1988.

Al-Hamid, Hisyam Kamal Abdu. Ya'jūj Wa Ma'jūj Qādimun. 1st ed. AlQāhirah: Dār al-Kitāb al-'Arabi, 2006.
Ali, Mahmud Athiyah Muhammad. Tanda Berakhirnya Dunia: Menyingkap Tabir Datangnya Kiamat Berdasarkan Al-Qur'an. Solo: Tinta Medina, 2014.

Al-Mubayyadh, Muhammad Ahmad. AlMausū'ah Fì Al-Fitan Wa AlMalāhim Wa Asyarāti as-Sā'ati. Al-Qahirah: Muassasah AlMukhtār Li An-Nasyr wa AtTauzì', 2006.

Al-Qudsy, Musa Turoichan. Munculnya Dajjal Dan Imam Mahdi Di Akhir Zaman (Terjemah Fafirru Ila Allah). Pertama. Surabaya: Ampel Mulia Surabaya, 2004.

Al-'Uraifi, Muhammad bin Abdirrahman. Al-ālam Al-Akhīr: Ahdāś AlQiyāmah as-Șugrā Wa Al-Kubrā Wa Mā Ba'dahā Bi as-Șuwar Wa Al-Tauḍihāt Min Al-Qur'ān Wa as-Sunnah as-Șahīhah. Riyadh: Dar at-Tadmuriyyah, 2012.

Al-Wabil, Yusuf bin Abdillah bin Yusuf. "Asyrātu As-Sā'ati." Dar Ibnu alJauzi, 1983.

Al-Walid, Mahmud Rajab Hamadi. Kasyfu Al-Minan Fī 'Alāmāti AlSā'ati Wa Al-Malāhim Wa AlFitan: Ru'yat Limustaqbal Al'Alam Al-Islāmi Fĩ Dhau'i Al-Kitāb Wa Al-Sunnah. Beirut: Dār ibnu Hazim Li at-thibā'ah wa an-Nasyr wa at-Tauzi', 2002.

. Kasyfu Al-Minan Fī 'Alāmāti asSā'ati Wa Al-Malāhim Wa AlFitan: Ru'yat Limustaqbal Al'ālam Al-Islāmi Fī Dhau'i Al-Kitāb Wa as-Sunnah. Beirut: Dar ibnu Hazim La aThiba'ah wa an-Nasyr wa at-Tauzii', 2002. 
As-Sa'labi, Mustafa Abu an-Nasr. Sahih Asyratu As-Sā'at Wa Wasfu Liyaumi Al-Ba'si Wa Ahwāli Yaumi Al-Qiyāmah. 2nd ed. Jeddah: Maktabah al-Sawāadi li al-Tauzi', 1994.

As-Sufi, Mahir Ahmad. Asyrāt Al-Sā'ati Al-'Alāmāt Al-Kubrā. Beirut: Syirkah Abnā Syarīf al-Anshārī li al-Thibā'ah wa al-Nashr wa atTauzī', 2010.

Bakri, Tubagus Ahmad. Saifu Ad-Dharīb. Purwakarta, 1922.

Baried, Baroroh. Pengantar Teori Filologi. Jakarta: BPFF UGM, 1994.

Dittmer, Jason. "Of Gog and Magog: The Geopolitical Visions of Jack Chick and Premillennial Dispensationalism." ACME: An International E-Journal for Critical Geographies 6 (2007): 278-303.

Fatkhullah, Faiz Karim. "Saifu Aḍ Ḍharīb: Text Edition and Study of Signs of Doomsday." Universitas Padjadjaran, 2019.

Fatkhullah, Faiz Karim, Tajudin Nur, and Undang Ahmad Darsa. "The Reception Of Dajal Story In The Saifu Ad-Dharib." Humanus 17, no. 1 (March 20, 2018): 37. https://doi.org/10.24036/humanu s.v17i1.8779.

Fitriyani, Winda. "Naskah Layang Dajjal 'Kebangkitan Makhluk Laknatullah' Suntingan Teks Dan Terjemahan." Universitas Padjadjaran, 2017.

Ghaits, Muhammad Ghaits bin. "Ahādis Asyrāth As-Sā'ati Wa Fiqhuhā." Jami'ah Muhammad al-Khamis
Mamlakah al-Garbiyyah Rabat, 2013.

"Hadis Shahih Muslim No. 169." Accessed April 25, 2019. http://www.carihadis.com/lihat.ph p?kitab=Shahih_Muslim\&id=1 .

Jabrohim. Metodologi Penelitian Sastra. Edited by Jabrohim. 3rd ed. Yogyakarta: PT Hanindita Graha Widya, 2003.

Lee, Lydia. "The Enemies Within: Gog of Magog Modern Political Identifications of Gog." HTS Teologiese Studies/Theological Studies 73, no. 3 (2017): 1-7.

Muslim, Abi al-Husain bin al-Hajjaj bin. Sahih Muslim. Riyadh: Dar alSalam Li al-Nashr wa al-Tauzi', 2000.

Mutaqin, Imam Cici. "Naskah Nawadirul Ulum 'Tanda-Tanda Hari Kiamat': Edisi Teks Dan Terjemahan." Universitas Padjadjaran, 2016.

Pérez, Sandra Sáenz-lópez. "La Representacion De Gog y Magog." AEA LXXVIII, no. 311 (2005): 263-76.

Railton, Nicholas M. "Gog and Magog: The History of a Symbol." The Evangelical Quarterty 1 (2003): 23-43.

Robson, S.O. Prinsip-Prinsip Filologi Indonesia. Jakarta: Pusat Pembinaan dan Pengembangan Bahasa dan Universitas Leiden, 1994.

Salim, Ach. Ghazali. "Peran Kitab Suci Al- Qur'an." OKARA 1, no. X (2015): 1-16. 
Teeuw, A. Sastra Dan IImu Sastra. 5th ed. Bandung: Pustaka Jaya, 2015.

Winarno, Hery H. "Burung Garuda, Dewa Atau Elang Jawa | Merdeka.Com," 2017. https://www.merdeka.com/khas/b urung-garuda-dewa-atau-elangjawa.html.

Winarno, Hery $\quad H$. "Https://Www.Merdeka.Com/Kha s/Burung-Garuda-Dewa-AtauElang-Jawa.Html." Merdeka.com, 2017. 